\title{
Role of Internal Medicines in the Management of Infections w.s.r. to Viral and Fungal Diseases: A Review
}

\author{
Available online at www.hjhs.co.in \\ REVIEW ARTICLE \\ Neeraj Kanungo *,a, Vijayata Kanungo ${ }^{\text {b }}$, Ajit Kumar Ojha ${ }^{c}$ \\ ${ }^{a}$ Assistant professor in Kayachikitsa department, Govt.Ashtang Ayurved College and \\ Hospital, Indore (MP) India \\ ${ }^{\mathrm{b}}$ Reader in Department of Panchkarma, Shubhdeep Ayurveda Medical College and Hospital, \\ Indore (MP) India \\ ${ }^{\mathrm{c}}$ Assistant professor in Panchkarma Department, Govt.Ashtang Ayurved College and \\ Hospital, Indore (MP) India \\ DOI 10.22270/hihs.v6i3.102
}

\begin{abstract}
Ayurveda works towards the prevention and management of various health problems, Ayurveda also suggests many natural ways to promote general health. Ayurveda in this regards provides several modalities for controlling infectious diseases which described as Sankramak Roga in Ayurveda. As per Ayurveda these Sankramak Roga mainly arises due to the vitiated state of Doshas and this vitiation arises by microbial toxins in case of infectious diseases. Therefore Doshas pacifying medicines recommended controlling infections. Ayurveda drugs like Kapura, Neema, Guduchi, Tulsi and Vacha, etc. helps to treat such pathological conditions. The present scenario of pandemic disaster requires an approach where Ayurveda and modern science can join hand together to combat against this situation. The consequences of viral infections also increases susceptibility towards other infections i.e.; fungal diseases. Considering these all facts this article explored Ayurveda as well as modern approaches for the management of various types of Sankramak Roga w.s.r. to viral and fungal infections.
\end{abstract}

Keywords: Ayurveda, Microbes, Viral Infections, Fungal Infections, Doshas

\section{Introduction}

The ancient Ayurveda scholars have mentioned Sankramak Roga as communicable diseases which can transmit from diseased to healthy person and in this way causes mass destruction. The pandemic health issues always affected mankind since ages of civilization and recently world is also facing pandemic health issue of Covid-19 disease. The preventive and therapeutic measures suggested by medical fraternity helping people to remain healthy in present scenario.

Ayurveda along with modern therapy can provide an effective way to controlling consequences of infectious diseases. Ayurveda on the basis of mode of transmission classified Roga as
Upsragaja and Sansargaja. As per ayurveda the pathophysiology of infectious diseases depends upon state of Dhatu which ultimately alter Doshas, Srotas and Agni. Therefore drugs which potentiate Dhatu and Agni, balances Doshas and clear obstruction of Srotas are useful to suppress pathogenesis of infectious diseases.

As per Ayurveda Covid-19 can be correlated with Agantuja vyadhi in which Sannipata Jwara is main feature of disease. Agantu causes infection with Abhyantara Roga marga and Pranavaha Srotadushti arises. As per ayurveda Jwara, Kasa and Svasa are main symptoms of current pandemic problem. Pathogens responsible for Sankramak roga can transmit via different mode of transmission from one to another person therefore 
susceptibility of an individual towards disease causative organism play an important role towards spread of disease. The good immune system decreases susceptibility towards disease causative organism therefore Ayurveda approaches which can restore immune system also recommended for controlling infectious disease. Anti-infective, analgesics and anti-inflammatory drugs along with Rasayana therapy can provides symptomatic as well as pathological relief in such conditions. Shodhana therapy and disciplinary conduct of daily and dietary habits can also help to remain free from infectious diseases. (1-5)

2. Prevention and Treatment of Infectious Diseases
Drugs which offer Kapha pacifying capacity and relieve symptoms of Kasa \& Shwasa can be used. Neem, Ginger, Guggulu, Amla, Guduchi, Punarnava, Pippali, Turmeric, Bhallatakasava, Tulasi and Vasa, etc. can be advised for therapeutic management of different infectious diseases. Ushna and Katu properties these drugs impart Vishaghna action thus control microbial toxins inside the body and suppress pathological progression of infectious diseases. (6-7) The specific therapeutic effects of ayurveda approaches in Sankramak Roga depicted in Figure 1. The ayurveda drugs used for viral and fungal infections and their effects mentioned in Table $\mathbf{1}$ and $\mathbf{2}$.

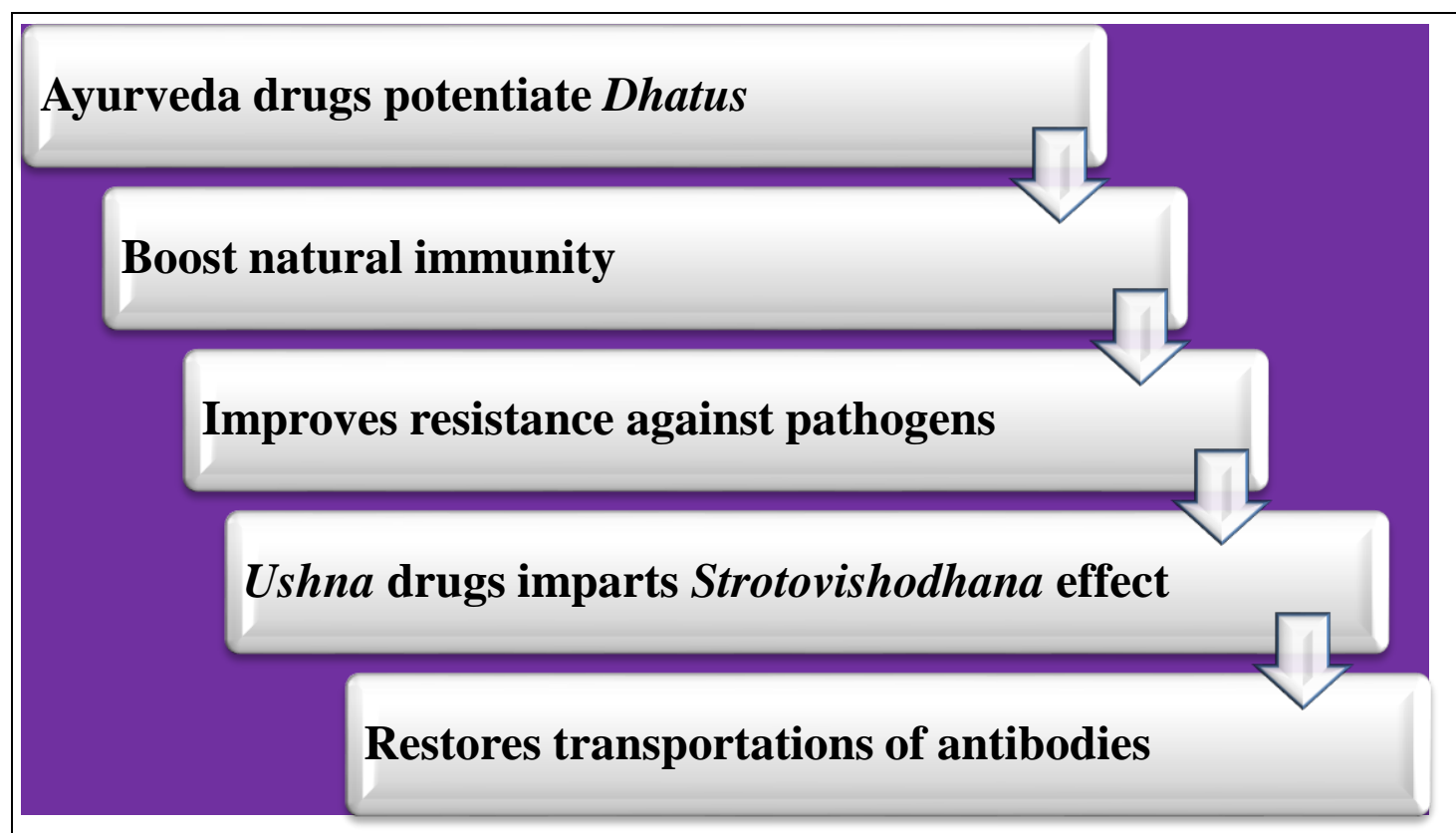

Figure 1. Effects of Ayurveda therapy in Sankramak Roga

Table 1. Ayurveda drugs and their effects in viral infection

\begin{tabular}{c|c|l|}
\hline S. No. & $\begin{array}{c}\text { Herbs/plant/ } \\
\text { formulation }\end{array}$ & \multicolumn{1}{c}{ Effect in viral infections } \\
\hline $\mathbf{1}$ & Amla & $\begin{array}{l}\text { Cure fevers, restore gastric strength, improves immunity, } \\
\text { remove toxins from body and boost healing process naturally. }\end{array}$ \\
\hline $\mathbf{2}$ & Pippali & $\begin{array}{l}\text { Possess antimicrobial property, reduces microbial load in case } \\
\text { of infections, cure digestive power thus boost immunity and } \\
\text { helps to suppress fever. }\end{array}$ \\
\hline $\mathbf{3}$ & Guggulu & $\begin{array}{l}\text { Nourishes body, boost natural healing process, enhances } \\
\text { leukocyte migration during infection and can be used as } \\
\text { antipyretic drug against infection induced fever. }\end{array}$ \\
\hline
\end{tabular}




\begin{tabular}{c|c|l|}
\hline $\mathbf{4}$ & Punarnava & $\begin{array}{l}\text { Improves immune power, control viral load and maintain } \\
\text { circulation of body thus alter leukocyte migration during viral } \\
\text { infections. }\end{array}$ \\
\hline $\mathbf{5}$ & Turmeric & $\begin{array}{l}\text { It is anti-microbial drug, reduces fever and fatigue, suppress } \\
\text { microbial load and boost immune response. }\end{array}$ \\
\hline $\mathbf{6}$ & Neem & $\begin{array}{l}\text { It helps to prevent infections, possess antiseptic and anti-viral } \\
\text { action. }\end{array}$ \\
\hline $\mathbf{7}$ & Guduchi & $\begin{array}{l}\text { Used as an antimicrobial agent, reduces viral infection, } \\
\text { suppress throat infections, improve immunity and control } \\
\text { pathological progression of infectious diseases. }\end{array}$ \\
\hline
\end{tabular}

The drugs mentioned above potentiate Agni thus nourishes body and boost strength of Dhatus hence improves inherent immunity. These natural drugs eliminate toxins, control metabolic activities and nourish Dhatus by virtue of

Table 2. Ayurveda drugs for fungal infections their Guna. The Vishaghna effect of these drugs pacifies aggravated Doshas, purifies Rakta Dhatu, clears Strotas due to their Strotovishodhana effect and relieves symptoms of throat infections. (7-9)

\begin{tabular}{|c|c|c|}
\hline S. No. & $\begin{array}{l}\text { Herbs/plant/ } \\
\text { formulation }\end{array}$ & Effect in fungal infections \\
\hline 1 & Rasonam & $\begin{array}{l}\text { Improves circulation thus facilitate removal of toxins and } \\
\text { antibodies. Disinfectant and detoxifying effect of Rasonam } \\
\text { provide symptomatic relief in skin infection. }\end{array}$ \\
\hline 2 & Punarnava & $\begin{array}{l}\text { Enhances natural immunity, control infections, alter cell- } \\
\text { mediated immune response and facilitate leukocyte migration. }\end{array}$ \\
\hline 3 & Katuki & Prevent skin infections and helps in nutritional supply. \\
\hline 4 & Yashtimadhu & $\begin{array}{l}\text { Eliminate toxins from body, cure inflammation in case of } \\
\text { fungal infection, reduces irritation due to its cooling effect and } \\
\text { imparts soothing property. }\end{array}$ \\
\hline 5 & Ashwagandha & $\begin{array}{l}\text { Possess rejuvenating, astringent, immune-boosting and anti- } \\
\text { inflammatory properties thus help in fungal infections. }\end{array}$ \\
\hline 6 & Tulsi & $\begin{array}{l}\text { This ancient plant known to possess antibacterial and } \\
\text { antiseptic properties thus relief symptoms of infection. } \\
\text { Maintain supply of pure body and improves immunity thus } \\
\text { effectively resist infectious conditions. }\end{array}$ \\
\hline
\end{tabular}

Ayurveda formulation Dadrughni vati used as antifungal drug since it cure skin infection, Chandraprabha vati also used to prevent fungal infections. Another formulation Hinguliya manikyarasa provides antifungal action due to the presence of ingredients such as; Gandhak, Haritala and Hingula. Arogyavardhini vati is useful in case of fungal skin infection. Ayurveda herbo-mineral formulations such as; Abhraka and Tamra bhasma helps in purification thus relives skin manifestations related to fungal infection.
These ayurveda drugs control aggravated Doshas, purifies blood and regulates circulatory process of body therefore considered useful for fungal infection. Katu Vipaka, Laghu Guna and Ushna Veerya of these drugs provide relief in Kushta.

There are many Ayurveda drugs which clean toxins when used as Lepa for external purpose in fungal infection. The soothing, anti-inflammatory and Shodhka effects of ayurveda drugs give imparts health benefits against fungal infection. 
The Kashaaya and Kshraia properties of natural drugs control effects of microbial infections. (10-11)

\section{Conclusion}

Ayurveda the traditional way of health management described several measures to prevent and treat diseases induced by microbes. Ayurveda mainly focuses for improving immunity which gives disease resistance power. Ayurveda drugs nourish Dhatus, facilitate antibodies migration, control cell-mediated immunity, clear Srotodushti and strengthen Agni therefore restore strength against infectious diseases. Saha Bhojnat, Nihsvasat, Gatrasansparsat, Vastramalyanulepanat and Sahashaiyasanat, etc. are mode of transmission of infectious diseases. Medical fraternity advocated social distancing and concept of home quarantine of disease person to control spread of infections, these preventive measures restrict communication of infectious diseases therefore everyone should adopt them during pandemic situation. Ayurveda formulations such as; Pipplyadi Yoga, Triphala, Gangadhar Churna, Sudhasar Rasa and Satavari Kalk, etc. possessing Krimighna effects, restore Ojas, impart antioxidant effect and improves natural healing process therefore useful in microbial infections. Shodhana procedures (Virechana and Raktmokshan, etc.) also advocated in Ayurveda for treating microbial infections which purify Rakta and eliminates vitiated Doshas/toxins.

\section{Acknowledgements}

Authors are very thankful to Himalayan Journal of Health Sciences for publishing our article.

Financial Disclosure statement: The author received no specific funding for this work.

\section{Conflict of Interest}

The authors declare that there is no conflict of interest regarding the publication of this article.

\section{References}

1. Agnivesha, Charaka Samhita elaborated by Charaka \& Drudhabala with Ayurveda, Deepika Commentary by Chakrarapanidatta, edited by Vaidya Jadavaji Trikamji Acharya. Varanasi: Choukhambha Surbharati Prakashan. Reprinted 2011; Vimanasthana chapter 6.

2. Indradeva Tripathi, Rasaratna Samuccayah with Rasa Prabha hindi commentary. Varanasi: Choukhamba SanskritBhavan; 2007.

3. Belapurkar P, Goyal P, Tiwari-Barua P. Immunomodulatory effects of triphala and its individual constituents: A review. Indian J Pharm Sci. 2014; 76:467-475.

4. Acharya YT. Susrutha Samhitha of Susrutha with Dalhana Tika. Vara-nasi: Chaukhambha Orientalia; 1992. (Sushrut, Sutrasthan 15/48).

5. Shukla N. Ayurvedic approach to communicable disease - An overview. Open Access Scientific Reports; 2010.

6. Patwardhan B, Payyappalli U. Ayurveda and antimicrobial resistance. J Ayurveda Integr. Med. 2018;9(2): 85-86.

7. Dr. Pradyumna M. Pasarkar, Dr. Shailendra K. Pund, Dr. Khemraj V. Pawar, Ayurveda Perspective on Infectious Disease and their Management through Ayurveda Dravya (Natural Drugs). WJPMR. 2020;6(6): 154-156.

8. Last JM, editor. Dictionary of Epidemiology. $2^{\text {nd }}$ ed. New York: Oxford University Press; 1988. p. 42.

9. Girijadayalu, S., Bhela Samhita. Varanasi: Chaukhambha Bharati Academy;1999.

10. Harish Chandra Singh Kushwaha, Charak Samhita - second part. Varanasi: Chaukhamba Orientalia; Reprint 2012.p.1.

11. Shastri Pandit Kashinath, Chaturvedi Dr. Gorakhnath. Reprint Edition. Hindi Commentary: Charak Samhita Chikitsasthan 3/110-111. Varanashi: Chaukhambha Bharati Akadami Publication; 2007.p.124 